\title{
Tissue Engineered Animal Sparing Models for the Study of Joint and Muscle Diseases
}

\author{
Ali Mobasheri and Mark Lewis \\ Additional information is available at the end of the chapter \\ http://dx.doi.org/10.5772/55563
}

\section{Introduction}

The aim of this book chapter is to highlight the fact that regenerative medicine and tissue engineering have important consequences for animal research and can be exploited to develop powerful animal sparing in vitro models. The main objective of the authors is to encourage researchers to consider designing, developing, utilizing and exploiting biomimetic alternatives to in vivo animal models. This chapter will focus on some of the most popular in vitro models that have been developed for skeletal muscle and articular cartilage. Refining these animalsparing models will advance tissue engineering and regenerative medicine and may replace animal models and significantly reduce our dependence on animals in research. Over the last few decades, a number of different animal models have been developed to support preclinical and clinical research to address hypothesis or curiosity driven research. However, many of the currently available animal models are not suitable models for human disease. 'Evidence-based medicine' refers to the ability to locate, critically appraise and incorporate evidence into clinical practice. This important branch of medicine seeks to assess the strength of evidence of the risks and benefits of treatment (or lack of treatment) and relies on well-established and reliable models to facilitate the research that underpins the decision-making process. Clinical research and evidence-based medicine therefore rely on the availability of reliable model systems that can be used for translational research. Using in vitro culture models eliminates some but not all of the problems associated with clinical research with human subjects and animal models of disease. In many cases culture models help to overcome barriers and allow researchers to gain a better understanding of disease pathogenesis, characteristics and responses to treatments. This chapter will focus exclusively on animal sparing in vitro models of muscle and joint tissues that have been developed to mimic these musculoskeletal structures. Many of these models are well established and possess similar morphological, histological, biochemical 
and molecular characteristics of muscle and joint tissues in vivo. These in vitro models allow researchers to perform original, hypothesis-or curiosity-driven research without using animals while still accurately mimicking musculoskeletal tissues in real life. In vitro models also enable screening for new drugs to treat musculoskeletal diseases in a more efficient and cost-effective way such that real progress is achieved more quickly.

\section{Biomimetic models}

Tissue engineering is an interdisciplinary field that applies the principles of biology and engineering to the development of functional substitutes for damaged tissue [1]. The loss or failure of an organ or tissue is one of the most frequent, devastating, and costly problems in human health care. By applying the basic principles of engineering and cell biology tissue engineering is helping us to move toward the development of biological substitutes that restore, maintain, or improve tissue function or a whole organ [2]. The new tissues can be used as test beds in basic research and development and have potential for future use in transplantation and reconstructive surgery [3].

Biomimetics is defined as the study of the structure and function of biological systems as models for the design and engineering of biomaterials. The term biomimetics was coined by Otto Schmitt in the 1950s for the transfer of ideas and analogues from biology to technology [4]. It generally refers to human-made and engineered processes, substances, devices, or systems that imitate and therefore mimic natural processes and biological systems. It extends to the study of the formation, structure and function of biological substances and materials (i.e. enzymes, polymers, surfaces) and biological mechanisms or processes (i.e. catalysis, protein synthesis) aimed at synthesizing similar products by artificial mechanisms that mimic natural ones. Therefore, a biomimetic model aims to mimic the structure and function of a biological system in its structure or function.

Organ, tissue and cell culture have been used for decades as biomimetic models of cells, tissues and organs. The pioneering work of eminent scientists such as Sydney Ringer, Wilhelm Roux and Ross Harrison from 1880 to the early 1900s helped to establish the principles and methodology of tissue culture. Ringer developed salt solutions containing the chlorides of sodium, potassium, calcium and magnesium suitable for developing organ culture. He used this model to maintain the beating of an isolated animal heart outside of the body. Roux maintained a portion of the medullary plate of an embryonic chicken in a warm saline solution for several days, establishing the principle of tissue culture. Harrison published the first paper that successfully introduced tissue culture to settle the argument of how nerve fibres originated [5]. Although other scientists had examined cells in vitro several decades earlier, none of them had successfully manage to culture them and it was Harrison who first successfully overcame basic culture problems and created a technique that other investigators could follow [6]. The first permanent fibroblast-like cell line was developed by Earle in 1943 from subcutaneous mouse tissue [7]. This allowed the development of techniques for generating the first human "transformed" cell line, the HeLa cell, derived from a cervical carcinoma [8]. This resulted in the 
advent of cell and tissue culture. This technique is arguably one of the best and earliest examples of biomimetics and has become one of the foundations of modern biomedical research. It has been used for decades to grow tissues and cells isolated from living organisms. Tissue culture generally refers to the growth of human or animal cells in vitro. However, the term tissue culture can also be used to refer to the culturing of pieces of tissue, i.e. explants or whole organs in culture. It is an invaluable tool for the study of cell biology and pathology.

Organ, tissue and cell culture are powerful reductionist techniques that have allowed us to study the function of biological systems. However, they are not suitable models for every type of biological question. For example results from cell culture are often not comparable to those derived from in vivo studies using whole animals e.g. in studies of drug action and metabolism since the drugs are metabolized in vivo but not in vitro. Furthermore, primary or derived culture is rarely able to accurately model the physiological functions of an organ because of the difficulties associated with re-creating neural, circulatory and endocrine signals in vitro. Nevertheless, tissue culture remains a powerful technique and has many animal sparing applications.

\section{Biomimetic models and their potential for replacing, refining and reducing laboratory animal models in research}

The National Centre for the Replacement, Refinement and Reduction of Animals in Research (NC3Rs) based in London, UK recently carried out some research to demonstrate that poor or incomplete reporting of studies that use animals have made it difficult to derive the maximum scientific knowledge from animal research. In addition, over the last few decades many research laboratories in academia and industry have used laboratory animals unnecessarily. A survey published by the National Institutes of Health (NIH) Office of Laboratory Animal Welfare (OLAW $)^{1}$, and the UK's National Centre for the Replacement, Refinement and Reduction of Animals in Research $\left(\mathrm{NC}_{\mathrm{R}} \mathrm{s}^{2}\right)$ has demonstrated that many peer-reviewed scientific publications reporting publicly funded animal research from the UK and US lacked key information on how the study was designed, conducted and analysed, which could limit their value in informing future scientific studies and policy. In response to these findings the NC3Rs has recently published the ARRIVE (Animal Research: Reporting In Vivo Experiments) guidelines [9], which were specifically introduced to improve reporting of animal experiments. These new guidelines have been published in PLoS Biology and several other prestigious scientific journals. Many biomedical research organisations and international scientific societies have already begun to implement these guidelines. The guidelines were developed by the NC3Rs to improve standards of reporting and ensure that the data from animal experiments can be fully evaluated and utilised. The ARRIVE guidelines consist of a 20-point checklist of the essential information that should be included in publications reporting animal

1 http://grants.nih.gov/grants/olaw/

2 http://www.nc3rs.org.uk/ 
research. Developed in consultation with the scientific community, including researchers, statisticians, journal editors, and funders, the guidelines request essential information that should be included in publications reporting animal research. Essentially the guidelines are intended to improve reporting of research using animals; guide authors as to the essential information to include in a manuscript, and not be absolutely prescriptive; be flexible to accommodate reporting a wide range of research areas and experimental protocols; promote reproducible, transparent, accurate, comprehensive, concise, logically ordered, well written manuscripts and improve the communication of the research findings to the broader scientific community. The UK's major bioscience funding bodies, including the Medical Research Council, the Biotechnology and Biological Sciences Research Council, Department for Environment, Food and Rural Affairs (Defra ${ }^{3}$ ), the Natural Environment Research Council $\left(\mathrm{NERC}^{4}\right)$, the European Research Council $\left(\mathrm{ERC}^{5}\right)$ and the Wellcome Trust ${ }^{6}$, have all incorporated adherence to the guidelines into a revised version of 'Responsibility in the use of animals in bioscience research: Expectations of the major research council and charitable funding bodies', which was originally published in May 2008.

Although the ARRIVE guidelines are primarily aimed at scientists writing up their research for publication and for those who are involved in peer review and intended to improve standards of reporting data from animal experiments, they have also highlighted the potential of biomimetic and tissue engineered in vitro models for replacing, refining and reducing the use of laboratory animals in research.

\section{Biomimetic models of muscle}

Cells - Skeletal muscle cells can be cultured in vitro following their isolation from muscle tissue. The main advantage of in vitro cultures of skeletal muscle precursor cells (MPCs) is the faithful recapitulation of the events that occur in vivo during development and regeneration whereby mononuclear MPCs fuse together under the correct conditions to form multinucleate myotubes - essentially nascent muscle fibres. Skeletal muscle development occurs in the somites; segments of paraxial mesoderm which form on either side of the neural tube [10], which is further divided into the epaxial and hypaxial dermomyotome [11]. Cells in the dermomyotome migrate and form the myotome, and transiently express the paired box transcription factors Pax 3 and 7, and Muscle Regulatory Factors (MRFs) Myf5, MyoD and Myogenin [12], which regulate myotube formation. The expression of these transcription factors has been shown to be critical for 'normal' muscle formation during development $[13,14]$ and null mutations of some of these genes can be lethal during the early post-natal period [15, 16]. Whilst the myotome gives rise to the musculature of the trunk, Pax $3+$ cells migrate out of the hypaxial

\footnotetext{
3 http://www.defra.gov.uk/

4 http://www.nerc.ac.uk/

5 http://erc.europa.eu/

6 http://www.wellcome.ac.uk/
} 
dermomyotome to the limb bud where they form the musculature of the limbs [10] under the influence of MRFs.

A subset of Pax 7/3+ cells have been identified in the limb buds and myotome in development, but fail to differentiate to form myotubes [17]. These proliferating precursor cells can adopt a position between the developed myofibre and the basal lamina during later muscle development $[17,18]$, which strongly indicates that this subset of progenitors form the satellite cells of post-natal skeletal muscle.

Satellite cells are the resident stem cells of skeletal muscle tissue, which provide additional nuclei to a muscle fibre during regeneration, such as may occur following muscle injury, damage or overload. Myonuclear addition is important in order for the muscle to effectively synthesise new proteins and thus adapt to specific stimuli, as well as generally maintain and increase its mass. Satellite cells are so called due to their anatomical location between the sarcolemma and basal lamina of a muscle fibre [19], and this parameter was for some time the only true 'marker' of these cells, achievable via electron microscopy. More recently however, a host of proteins which are expressed by satellite cells have been identified, including Pax 7 [20], Caveolin-1 [21] and myf-5 [22], and thus a molecular signature of these cells is being derived.

Satellite cells lie quiescent on the muscle periphery until becoming activated upon muscle damage/overload. The precise cause of satellite cell activation remain elusive ${ }^{7}$. However the fact that muscle injury leads to activation suggests that muscle damage itself may be the trigger or a factor secreted from the muscle may provide the initial cue [23]. The latter notion has support from the fact that Insulin Like Growth Factor-I (IGF-I) and indeed Hepatocyte Growth Factor (HGF) are released from the muscle following mechanical use or injury [24-29] and have been shown to activate satellite cells when exogenously administered [30-35]. Once activated, satellite cells proliferate extensively and express the transcription factors myf-5 and MyoD [36] as well as proteins specific to the myogenic lineage such as Desmin, before fusing with the damaged/overloaded fibres under the influence of myogenin [37] to provide additional myonuclei. As stem cells, satellite cells have the ability to self-renew and replenish the pool of quiescent cells following activation. The literature suggests that asymmetric distribution of a number of potential proteins is implicated in regulating self-renewal [38-40], causing some daughter cells to express pax 7 and MyoD, and thus commit to the myogenic lineage and undergo fusion, whereas a small portion fail to express MyoD or myf-5 and thus repopulate the satellite cell pool $[38,39,41]$.

Isolation and subsequent culture of MPCs (satellite cells when in their anatomical niche) can be conducted either by explant culture, whereby muscle tissue is minced and maintained in culture until MPCs migrate from the tissue [42, 43], or via enzymatic digestion, whereby the tissue is broken down completely to release all of the resident mononuclear cells [44, 45]. Following isolation, careful consideration of the culture techniques should be taken in order to standardise/optimise the desired experiments. Indeed, MPCs are sensitive to the media 
composition, and will either proliferate or exit the cell cycle and differentiate when exposed to various media compositions [46]. Furthermore, MPCs are sensitive to environmental factors, and will proliferate and fail to differentiate when exposed to low oxygen levels $[47,48]$ and similarly, serial passaging of MPCs also appears to negatively effect their ability to differentiate [49]. Finally, as the population of cells released from skeletal muscle tissue tends to be mixed in nature (e.g. MPCs, fibroblasts, pericytes, endothelial cells etc.), it is often favourable to further purify the MPCs prior to experimentation either via differential adhesion methods or magnetic separation, a methodology optimise in our laboratory [50], however these cells may contribute to the development of more biomimetic tissue (detailed in Figure 1 below).

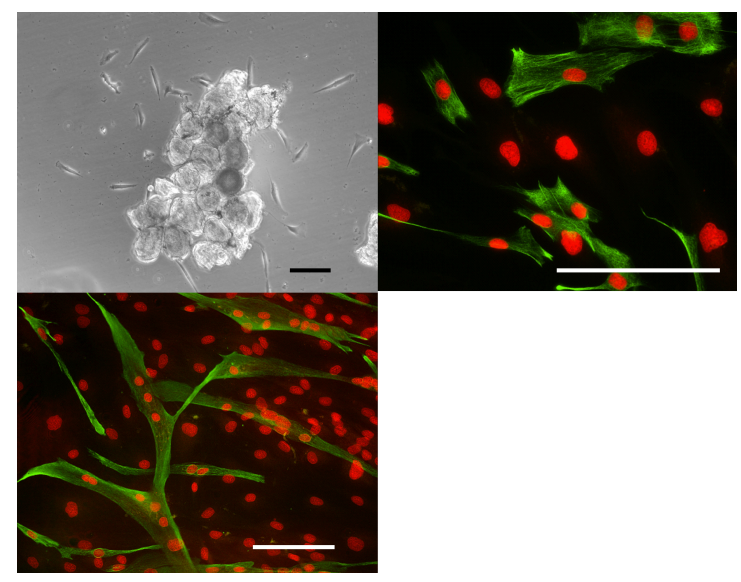

Figure 1. Skeletal muscle precursor cells can be isolated and cultured in vitro to recapitulate the events of development and regeneration. (A). Phase contrast photomicrograph of human skeletal muscle explant with MPCs migrating away from the tissue. (B) Immunostaining for Desmin (green) highlights those cells, which are commited to the myogenic lineage. (C) Desmin positive cells form multinucleate myotubes when stimulated to do so. Scale bars $=100 \mu \mathrm{m}$.

The isolation and characterisation of cells for utilisation in the development of in vitro skeletal muscle models is an important stage in the engineering process. However, the consideration of the influence of environmental factors in the creation of a biomimetic model is a necessity and will be explored below.

Environment - The skeletal muscle cell microenvironment (commonly referred to as the niche) supports the development of multi-nucleate myotubes (muscle fibres) in a number of ways: provision of directional cues, provision of topographical cues, availability of growth factors, transmission of mechanical signals and interactions with other cell types. Initial evidence that particular proteins within the skeletal muscle cell niche play critical roles in these processes and hence subsequent success of in vitro muscle cell behaviour, came with the establishment of the varying effects of ECM molecules on MPC proliferation and differentiation. Extracting bioactive ECM proteins from skeletal muscle for use as a growth substrate with in vitro MPC culture, results in superior proliferation and differentiation compared to standard growth substrates [51]. It is however the identification of interactions between ECM proteins and 
muscle cell surface proteins that has provided data regarding the requirements for successful in vitro culture of MPCs.

Particularly, integrins and proteins of the Dystrophin Associated Protein (DAP) complex have been demonstrated to play significant roles in MPC-ECM interaction in vitro. Indeed, the expression of $\alpha \mathrm{v}, \alpha \mathrm{v} \beta 3$ and $\alpha \mathrm{v} \beta 5$ integrins is evident in MPCs seeded on ECM substrates such as gelatin, fibronectin and vitronectin [52]. Moreover, blockade of $\alpha \mathrm{v}$ integrin using a specific antibody abolishes cell migratory capacity on fibronectin and vitronectin substrates [52]. The effect of ECM matrix components has also been demonstrated to influence the contractile phenotype of engineered skeletal muscle constructs. Increasing the content of ECM protein rich Matrigel, contributed to greater peak force of engineered constructs, whilst utilising growth factor reduced Matrigel did not affect the results [53]. This suggests that ECM matrix composition contributes to skeletal muscle maturation and phenotype to a greater extent than growth factors. These data provide clear evidence as to the importance of the ECM in the successful culture of MPCs in vitro.

The primary function of skeletal muscle in vivo is to provide vector force, for the controlled movement of the skeleton [54]. This directionality is achieved by the highly organised macro and microstructure of the skeletal muscle fibres and the surrounding $\mathrm{ECM}^{8}$. The recapitulation of this organised structure has been achieved through a variety of methodologies in vitro, including the use of both synthetic [55-58] and naturally derived polymers [45, 59-63]. These methods have provided both directional and topographical cellular cues, display varying amounts of resemblance and functionality to in vivo tissue. It has been suggested however, that the rigidity of synthetic polymers may affect the contractile properties and function of developed myotubes, whilst if the polymer is bio-degradable the alignment of cells may be affected by this process [64]. The use of naturally derived polymers (including fibrin and collagen) has in part been shown to overcome these issues. Particularly in a more biomimetic three-dimensional (3-D) structure, the rapid polymerisation of collagen matrices allows for an even distribution of the cells seeded, whilst the nanostructure allows for multiple attachment sites for the cells [64].

The provision of mechanical signals for the alignment and fusion of MPC sis an essential criterion for developing biomimetic constructs in vitro, since skeletal muscle in vivo is under continuous passive strain through the myotendinous junction. Such signals have been generated by the polymerisation of a biological substrate to a fixed structure in a variety of in vitro skeletal muscle models $[45,53,65,66]$. The anchored structures provide the necessary passive lines of strain, which provide the required signals to generate an orientated cellular architecture (See Figure 2 below). Indeed, it is clear that the 3-D structure and the presence of passive mechanical signals promote the alignment and fusion of MPCs to a greater extent than in conventional monolayer culture [45]. Furthermore, the morphological structure, gene expression and contractile phenotype are also representative of in vivo skeletal muscle [43, 45, 67].

8 Alec S.T. Smith, Rishma Shah, Nigel P. Hunt, Mark P. Lewis. The Role of Connective Tissue and Extracellular Matrix Signaling in Controlling Muscle Development, Function, and Response to Mechanical Forces. Seminars in orthodontics 1 June 2010 (volume 16 issue 2 Pages 135-142 DOI: 10.1053/j.sodo.2010.02.005) 


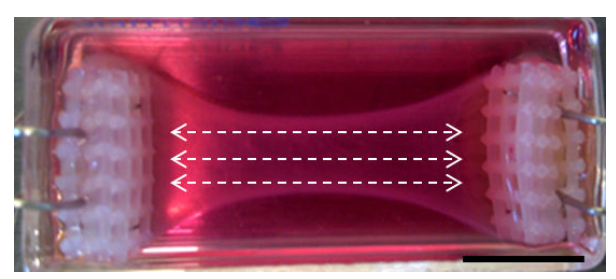

Figure 2. Biomimetic skeletal muscle constructs can be engineered from biological scaffolds. Example model of the typical macroscopic contraction of a type-1 collagen matrix, following 14 days in culture. Note the custom made anchors at either end, which provide predictable lines of longitudinal tension (illustrated by dashed arrows) to promote cell alignment and fusion in a single plane. Scale bar $=10 \mathrm{~mm}$.

A further advantage of using naturally derived polymers is the ability to easily stimulate, both mechanically and electrically, due to the innate mechanical compliance of the polymerised tissue. To this end, numerous investigations have employed such techniques to promote myogenesis and maturation of seeded MPCs [65, 68, 69]. In contrast, the effect of a combined mechanical stimulation protocol, contributed to a reduction in maturation of 3-D seeded myogenic cells compared to monolayer controls [66]. Nevertheless, the effect of increased mechanical signals for the promotion of MPC alignment and fusion, satisfies the desire for a biomimetic.

Skeletal muscle in vivo is comprised of myogenic progenitors, non-myogeninc progenitors and fibroblasts. The presence and influence of these non-myogenic populations has not been widely investigated, however, there is evidence to suggest a potential synergistic role in the development and maturation of skeletal muscle in vitro. The non-myogenic fibroblast population of cells has been shown to enhance skeletal muscle cell alignment, through contact dependent and independent mechanisms [70]. Data from 3-D skeletal muscle constructs also demonstrates an increased myogenin mRNA expression (marker of terminal differentiation) and increased peak force in a heterogeneous mixture of myogenic and non-myogenic cells, compared to myogenic only cultures [43]. Furthermore the expression of MMP-2 mRNA was greater in the heterogeneous cell population cultures, suggestive of greater matrix remodelling and fusion potential [43]. Together, these data illustrate the requirement of the non-myogenic cell population to recapitulate the in vivo skeletal muscle cell niche and associated biological processes. As such the incorporation of a heterogeneous population of cells should be utilised when developing skeletal muscle models in vitro.

Consideration of the body of data discussed above, indicates that an argument can be made that the ideal solution for a tissue engineered skeletal muscle construct would embrace the following:

1. Appropriate matrix signals.

2. Induction of alignment.

3. Presence of other cell types.

4. Mechanical stimulation. 
Provision of all of the cues simultaneously requires an approach that moves beyond conventional monolayer models. The structure defines function in skeletal muscle in vivo and all of the essential elements above can be combined using tissue engineering techniques. There are a number of systems that have moved towards this aim, however important validations for such systems is making comparisons against the in vivo tissue, physiological skeletal muscle. The systems described have shown the following features to date:

\begin{tabular}{lll}
\hline Parameter & Resemblance to In Vivo Tissue & System and References \\
\hline $\begin{array}{l}\text { Passive longitudinal tension generated by } \\
\text { anchor points }\end{array}$ & Myotendinous junctions & Collagen $[43,45,53,67,68,71] ;$ \\
\hline ECM & ECM protein composition & Collagen $[43,45,53,67,68,71] ;$ \\
& & Fibrin $[53]$ \\
\hline Morphology of cells & Alignment and fusion of seeded cells & Collagen $[45,53] ;$ Fibrin $[53,66]$ \\
& in a single plane & \\
\hline Active contractile phenotype (vector force) & Excitability and contractility profile & Fibrin $[60,62,65] ;$ \\
\hline $\begin{array}{l}\text { Passive contractile phenotype (vector force) } \\
\text { Cell-matrix passive contractile }\end{array}$ & Collagen $[43,45]$ \\
\hline $\begin{array}{l}\text { Myosin Heavy Chain (MYH) expression } \\
\text { interaction }\end{array}$ & $\begin{array}{l}\text { Increase in MYH-7 mRNA (slow } \\
\text { genotype) }\end{array}$ & Collagen $[67]$ \\
\hline $\begin{array}{l}\text { Responses to stimulation (mechanical and } \\
\text { electrical) }\end{array}$ & $\begin{array}{l}\text { Increases in gene and protein } \\
\text { expression similar to that with }\end{array}$ & Collagen $[68,71]$ \\
& exercise & \\
\hline
\end{tabular}

Table 1. Comparison of current biomimetic skeletal muscle models of in vivo skeletal muscle tissue.

There can now be a high degree of confidence that the aforementioned systems do recreate a significant aspect of in vivo skeletal muscle biology. Their use to-date with respect to providing a pre-clinical test bed for exercise, genetic, pharmaceutical and nutritional therapies is limited, however the system are now at a stage where such investigations are warranted.

\section{Animal models of cartilage for arthritis research}

Experimental models of degenerative joint diseases such as osteoarthritis (OA) and rheumatoid arthritis (RA) have been in existence for several decades [72]. Animal models of arthritis have been used to understand elements of the arthritic disease process in human patients [73]. They are powerful tools for studying pathologic changes in articular cartilage and bone in great detail, and can be used to evaluate mechanisms of erosive processes [73]. Animal models of arthritis are also used to evaluate potential anti-arthritic drugs for clinical use in human patients [74-76]. The capacity for predicting efficacy in human disease is one of the most important criteria in the selection of animal models [74]. The use of animals has been indis- 
pensable to the investigation of the aetiology, pathophysiology, and treatment of various forms of juvenile arthritis [77]. Animal models of rheumatoid arthritis (RA) are also well established and have a proven track record of predictability [74, 78]. These include rat adjuvant arthritis [79], rat and mouse type II collagen arthritis [80-82], and antigen-induced arthritis in several species. Many animal species are currently used in OA research [83]. Figure 3 summarises the main procedures and disadvantages of animal models of OA.

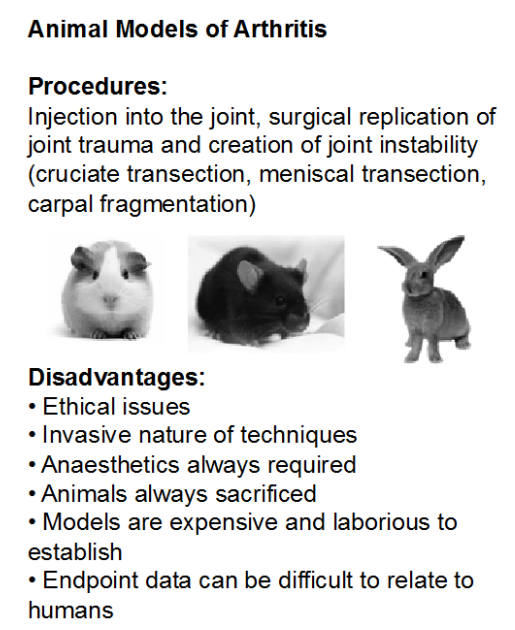

Figure 3. Procedures and major disadvantages of animal models of arthritis.

The animal models of OA include laboratory animals: mice, rats, guinea pigs, rabbits; farm animals: sheep, goats; and companion animals: dogs, cats, horses. Animal models of OA roughly fall into five categories; firstly, spontaneous OA, which naturally occurs in the knee joints of animals, such as guinea pigs and dogs, and has a similar pathogenesis to human OA $[84,85]$. Secondly, the surgical creation of joint instability, for example anterior cruciate ligament transection (ACLT) in dogs [86], meniscal tear model in rats [87], and collateral ligament transection in horses [88]. Thirdly, the surgical replication of joint trauma, for example the canine groove model [89], and carpal chip fragmentation in horses [90]. Fourthly, injection into the joint, for example papain [91], sodium mono-iodoacetate [92] and collagenase [93]. The final category is the knockout model, which deletes certain genes in mice resulting in the development of OA-like degenerative joint disease. For example the deletion of genes that code for type IX collagen [94], or the double deletion of biglycan and fibromodulin [95].

\section{Biomimetic models of cartilage}

Biomimetic models of articular cartilage were developed specifically for use in preclinical and clinical research long before the advent of tissue engineering and regenerative medicine, and 
the realisation that the development of these models is an elementary form of tissue engineering. One of the major advantages of articular cartilage is the fact that it is a relatively simple tissue consisting of a fairly homogeneous extracellular matrix and a single cell type. Also, cartilage is avascular, aneural and alymphatic $[96,97]$, a fact that was disputed for centuries until modern histological techniques were applied to study the tissue [97]. This unique property overcomes many of the obstacles that are involved in culturing other vascularised and innervated tissues. The following sections will discuss the most popular 2- and 3dimensional models of cartilage.

\subsection{2-Dimensional monolayer models of chondrocyes}

Two-dimensional in vitro models of chondrogenesis $[98,99]$ and methods for isolating and cultivating primary bovine chondrocytes were established in the early 1960's [100]. Methods have been published for human [101] and rabbit [102] cartilage. Primary chondrocytes [103-105] and SV-40 transformed chondrocyte-like cell lines [106] in monolayer culture are routinely used for basic research [107]. These models have been useful for studying the cell biology of cartilage and responses to drugs, pro-inflammatory cytokines, growth factors, nutrients and nutraceuticals. Chondrocytes are also able to survive freezing and cryopreserved cells retain the capacity to proliferate and synthesise ECM [108-111]. Although 2-D culture of chondrocytes is widely used (see Figure 4), this method suffers from several major weaknesses: 1). The cells de-differentiate to fibroblast-like cells after 4-5 passages; 2] They do not synthesise a genuine ECM. Early studies carried out in the 1960's showed that high-density culture preserves the chondrocyte phenotype; when cultured chondrocytes attain a certain cell density they re-acquire their rounded shape, stop dividing, and re-synthesize collagens and proteoglycans. Clusters of chondrocytes synthesize more proteoglycans than isolated chondrocytes [112]. If chondrocytes are actively engaged in ECM synthesis they do not concurrently synthesize DNA and so cannot divide and proliferate [112]. Interaction between chondrocytes is important for maintaining ECM synthesis and failure of interaction between chondrocytes leads to cell proliferation, a fact that has been exploited for expanding small numbers of isolated chondrocytes from limited amounts of clinical material.

Although chondrocyte survival and phenotype are regulated by culture conditions, the expression of the chondrogenic transcription factor Sox9 is of crucial importance [113]. The unique phenotype of the chondrocyte requires sustained expression of Sox9. This transcription factor plays an important role in the normal skeletal development and regulate the expression of other genes involved in chondrogenesis [114, 115].

\subsection{3-Dimensional cartilage culture systems - Alginate beads}

Alginic acid, also called algin or alginate, is an anionic polysaccharide that is widely distributed in the cell walls of brown algae. When extracted in granular or powdered forms, alginate is capable of absorbing 200-300 times its own weight in water. Due to its biocompatibility and simple gelation with divalent cations such as $\mathrm{Ca}^{2+}$, alginate is widely used for cell immobilization and encapsulation. Therefore, alginate beads offer an ideal substrate for developing support matrices for 3-dimensional chondrocyte culture (see Figure 5). Immobilization of cells 

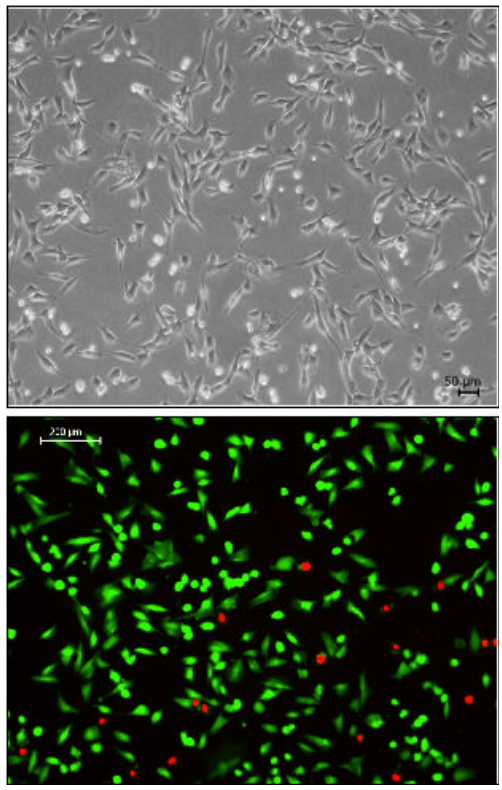

Figure 4. Dimensional cultures of primary chondrocytes. This culture system is widely used for basic research on chondrocyte biology and for drug toxicity testing.

along with macromolecules and biomaterials in alginate gels has become a well-established technology. Alginate beads are used in many biomedical and industrial applications. Cells immobilized in alginate gels maintain their differentiated phenotype during long-term culture due to the 3-dimensional environment of the gel network. In tissue engineering applications immobilized cells or tissue explants can be used as bioartificial organs as the alginate gel may function as a protective barrier towards physical stress and to avoid immunological reactions with the host. Chondrocytes can be encapsulated and maintained in calcium alginate beads or gels in 3-dimensional culture [116]. Avian and mammalian chondrocytes cultured in "semisolid" and "hollow" alginate beads exhibit a spherical shape as opposed to the fibroblastic morphology that is observed in monolayer culture [116]. The encapsulation methodology is suitable for the culture of chondrocytes in single beads, in multiwell dishes, or mass culture. Human and bovine adult articular chondrocytes have also been cultured in alginate beads and studies have shown that they retain their spherical shape and typical chondrocyte-like appearance for at least 5 weeks [117]. Alginate culture has also been used for cultivating intervertebral disc cells [118], nucleus pulposus and annulus fibrosus cells [119] and chondrocyte cell lines [120]. Aggrecan appears to be a major ECM molecule produced by alginate cultured chondrocytes. Sensitive assays have been developed for the quantification of glycosaminoglycans (GAGs) and nitric oxide (NO) produced by alginate cultures [121, 122]. Decorin is also synthesized in small amounts but it is rapidly lost from the agarose or alginate gel [117]. Alginate culture can be used to induce the re-expression of cartilage-specific genes (aggrecan and collagen II) by dedifferentiated human articular chondrocytes cultured in 
alginate beads. However, alginate is unable to restore the chondrocyte phenotype in SV-40 transformed cells [123]. Thus, articular chondrocytes embedded in alginate gel can produce de novo a matrix rich in collagens and proteoglycans [124]. The alginate culture system appears to represent a relevant model for maintaining primary populations of chondrocytes and inducing the redifferentiation of dedifferentiated human chondrocytes, especially when they have been expanded several times by passaging in monolayer culture. This approach is particularly useful when small cartilage biopsies are available. New approaches to cartilage tissue-engineering have combined isolated cells with polymer scaffolds (polyglycolic acid fibre meshes and alginate gels) for the purpose of generating new cartilage (neo-cartilage) [125].

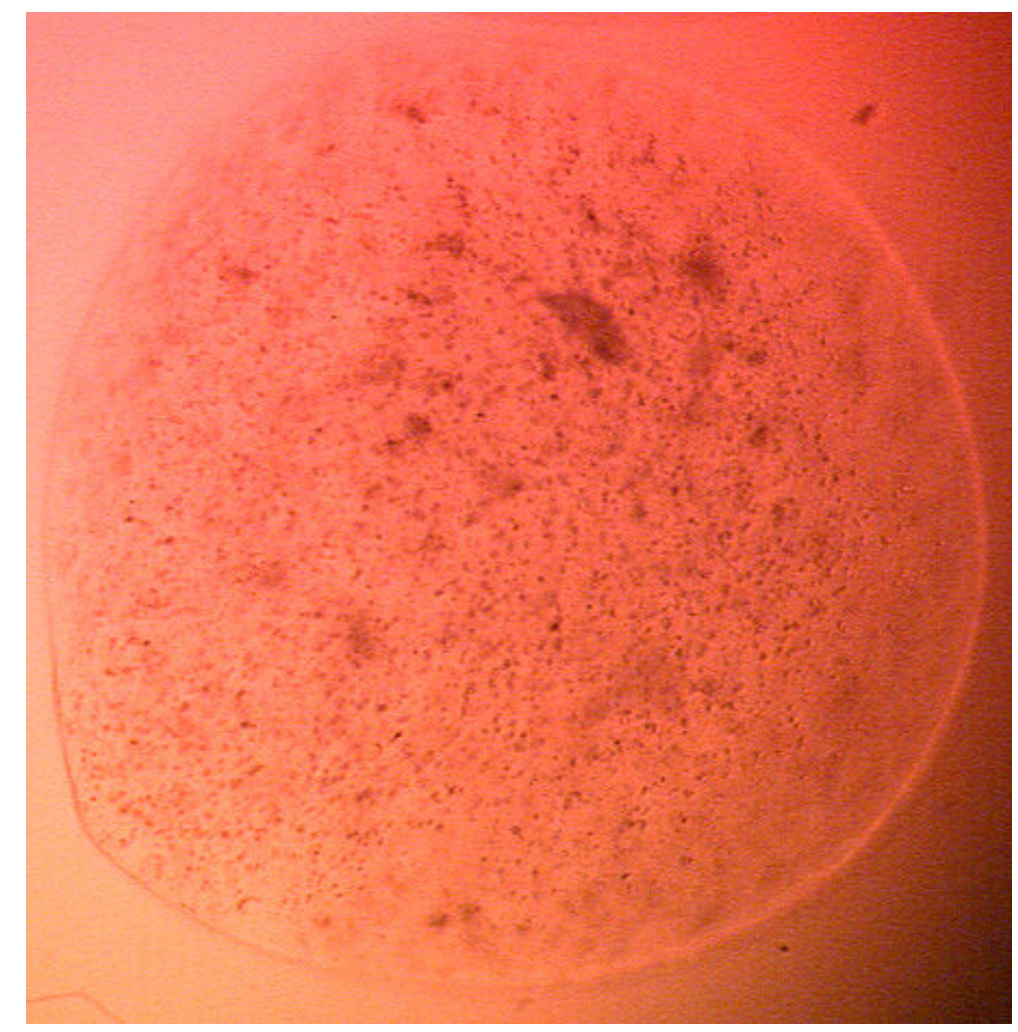

Figure 5. Chondrocyte culture in alginate beads.

\subsection{3-Dimensional cartilage culture systems - Agarose gels}

Agar is a gelatinous substance derived from algae. It is a mixture of two components: the linear polysaccharide agarose, and a heterogeneous mixture of smaller molecules called agaropectin. Agar and agarose have been used extensively for cell culture. Agar gels are have been used throughout the world to provide a solid surface containing medium for the growth of bacteria 
and fungi. As a gel, an agarose medium is porous and therefore can be used to re-create the 3dimensional environment that chondrocytes are accustomed to in articular cartilage. Culturing chondrocytes in agarose gels is actually very similar to alginate beads. Agarose gels proved to be particularly useful for studies on proteoglycans produced by avian [126], porcine [127] and bovine [128] chondrocytes. Agarose gels re-create a biomimetic 3-dimensional environment and stimulate ECM production by chondrocytes [129]. One of the most important studies on chondrocyte differentiation and redifferentiation was done using agarose gels by Benya and Shaffer [130]. As described earlier serial monolayer culture results in chondrocyte dedifferentiation and loss of phenotype. When chondrocytes dedifferentiate in monolayer culture they stop producing proteoglycans and type II collagen and instead secrete a different ECM consisting predominately of type I collagen and a low level of proteoglycan synthesis. Benya and Shaffer used agarose gels to demonstrate that dedifferentiated chondrocytes re-express the differentiated phenotype, producing proteoglycans and cartilage specific collagens [130]. The same outcome was achieved years later using alginate beads [131]. The original work of Benya and Shaffer demonstrated that a complete return to the differentiated collagen and proteoglycan producing chondrocyte phenotype is possible in agarose gels. Their results also emphasized the essential role of the spherical cell shape in the modulation of the chondrocyte phenotype and demonstrate a reversible system for the study of gene expression [130].

It is important to bear in mind that articular cartilage is subjected to dynamic compressive loading during normal activity and this influences chondrocyte metabolism. Mechanical forces are key determinants of connective tissue differentiation. Agarose gels, alginate beads and other 3-D gel systems are well established for studying the effects of dynamic compression on chondrocytes $[132,133]$. These techniques have gained significant popularity over the last two decades [134] and are still in use today to study patterns of gene expression in response to dynamic compression [135] and chondrocyte mechanotransduction pathways [136]. The preservation of the chondrocyte phenotype and the gradually increasing proteoglycan synthesis in agarose and alginate gels are promising methods for creating and engineering tissue implants for cartilage repair. These techniques can also be used to create new cartilage tissue from the joints of food producing animals (i.e. cattle, sheep, pigs) without having to sacrifice many smaller laboratory animals. This is an important area of cartilage tissue engineering with important consequences for animal research.

\subsection{3-Dimensional cartilage explant culture}

Explant culture is a technique used for the isolation of cells from a piece of tissue. Tissue harvested in this manner is called an explant. The tissue is harvested under sterile conditions and explants are placed in a cell culture dish containing growth media. In some explant cultures (i.e. skeletal muscle) progenitor cells migrate out of the tissue and grow on the surface of the dish. These primary cells can then be further expanded and exploited. In cartilage explant culture cells remain in their surrounding extracellular matrix and this accurately mimics the in vivo environment (see Figure 6). The method became established in the mid 1970's [137, 138] and was used to study the effects of prostaglandins [139-141] and rheumatoid synovium [142] on cartilage degeneration. The establishment of cartilage explant culture later became an important prelude to the development of monolayer culture systems of chondrocytes [143]. 


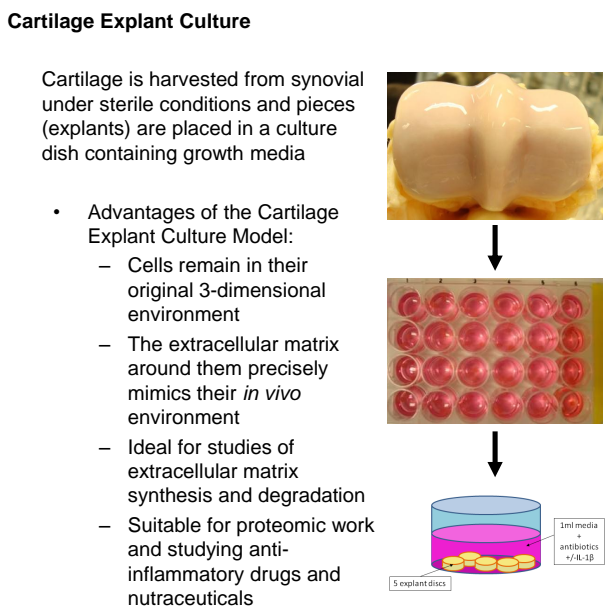

Figure 6. Overview of cartilage explant culture and its unique advantages.

\subsubsection{3-Dimensional High-Density and Pellet Cultures of Chondrocytes}

High-density culture is a 3-dimensional system that has been in the literature since the early 1970's. High-density suspension cultures of chondrocytes were initially used to study cartilage matrix protein synthesis by mammalian chondrocytes [144, 145], specifically mucoprotein [146] and proteoglycan [147] biosynthesis. In an important study published in 1977 the method was refined by von der Mark and von der Mark who used tissue culture plastic dishes on an agar base to monitor chondrogenesis of stage- 24 chick limb mesodermal cells in vitro by analyzing the onset of type II collagen synthesis [148]. This work demonstrated that highdensity cultures may be used for the analysis of cell specific types of collagen and provide a useful model for detailing the specific events in the differentiation of mesenchymal cells in vitro. Several subsequent studies used chick limb bud mesenchymal cells and chick sternal chondrocytes cultured in high-density to study chondrogenesis and proteoglycan synthesis [149] and fibronectin expression [150]. We have successfully used this model as a model for chondrogenic, osteogenic and tenogenic differentiation of mesenchymal stem cells and redifferentiation of dedifferentiated chondrocytes [151-154].

The high-density model exhibits a number of characteristics that make it particularly suitable for studies on chondrogenesis. In the first 24 hours of the high-density chondrocytes culture, cells form prechondrogenic areas composed of densely packed cells with intercellular interactions (gap junctions); these are surrounded by a perichondrium of flat fibroblast-like cells [155] resembling the situation during the early stage of chondrogenesis in vivo. The extensive cell-cell interactions during the first step of chondrogenesis are crucial for cell aggregation [156, 157]. The high-density culture system allows investigations during chondrogenesis starting from early blastema/mesenchymal stem cell condensations until cartilage maturation. This chondrogenic development is accompanied by enlargement of cartilage nodules, which 
is not due to cell proliferation but rather is due to appositional growth, which includes the transition of perichondral cells into chondrocytes. These conclusions are based on the almost complete absence of mitotic figures in cartilage and perichondrium and on the continuous increase in nodule size during cultivation [156].

\subsubsection{Co-cultures of chondrocytes and synoviocytes}

The synovial joint contains several important tissue components. These are articular cartilage, synovium, subchondral bone and fat pads (adipose tissue). Developing in vitro models that include all of these tissues is a major challenge. Co-culture models involve growing distinct cell types in a combined culture environment. The mixing of different cell types in culture is normally avoided, although it is becoming increasingly apparent that this approach can be used to model the cellular interactions that occur in vivo. Some studies of cellular interactions may actually require direct cell-cell contact in a 2-dimensional model where two different cell types are grown in mixture. Other studies may require proximity between the two cell types without any actual cell-cell contact. In this scenario keeping the two types apart can allow investigators to study the effect of one cell type on another. In a synoviocyte-chondrocyte coculture model synoviocytes grown on a filter insert may be stimulated with pro-inflammatory cytokines or other inflammatory mediators (i.e. phorbol esters such as phorbol myristate acetate (PMA), reactive oxygen species such as hydrogen peroxide or a combination of iron and ascorbic acid to simulate inflammation-like radical attacks) before bringing the "activated" cells in contact with chondrocytes. The use of cell culture inserts controls the physical contact and also the duration of that contact. It is also possible to grow different cell types on either side of the membrane, allowing a simulation of tissue behaviour to be built and studied. A coculture model of rat chondrocytes and a rabbit synoviocyte-like cell line (HIG-82, [158]), has been used to show that chondrocytes establish protective mechanisms against reactive oxygen species by interacting with synoviocytes [159]. This co-culture system presents a model to study mechanisms of inflammation in articular joints under well-defined conditions [159]. With the financial support of the National Centre for the Replacement, Refinement and Reduction of Animals in Research (NC3Rs) we have established a novel co-culture model of primary equine synoviocytes and primary equine chondrocytes for using equine joints derived from the abattoir ${ }^{9}$. We have not fully exploited this equine model system. However, since chondrocytes and synoviocytes are the main cell types present in articular joints, such coculture models have been used for metabolic studies [160] and have the capacity to recapitulate the inflammatory and catabolic events that occur in an arthritic joint.

\section{Conclusions}

Cell culture has a bright future. It is a fundamental and core component of tissue engineering and regenerative medicine. In this context the majority of studies carried out to date have used the well-established method of growing cells on 2-D plastic or glass substrates. There is

9 http://www.nc3rs.org.uk/researchportfolio/showcatportfolio.asp?id=254 
increasing use of 3-D cell cultures in research areas as diverse as drug discovery, cancer biology, regenerative medicine and basic life science research. There are many methods to facilitate the growth of 3-D cellular structures including nanoparticle facilitated magnetic levitation, gels, beads and solid matrices, self-assembling scaffolds and hanging drop plates. The culture of mammalian cells for toxicity testing or drug screening is likely to increase in the future. The biotechnology, pharmaceutical and cosmetic industries urgently need 3-D cell culture models that more accurately mimic living tissues and organs. This kind of technology will gradually increase in importance because of the vast array of natural and combinatorial products that require screening and the increased pressure from regulatory authorities to reduce animal testing. Most importantly, the pressure to reduce animal testing will stimulate scientists to create more robust biomimetic culture models and culture systems that may eventually eliminate the need for using animals for antibody production and vaccine development. There are many exciting and emerging areas that have not been reviewed in this chapter. This chapter has focused on biomimetic models of joint and muscle. Since joint tissues contain a diverse number of cell types, we have focused our efforts on in vitro models of chondrocytes and skeletal muscle cells.

It is becoming clear that $\mathrm{OA}$ is a disease of the entire joint rather than any single component and deterioration of associated skeletal muscle masses around an affected joint is a wellreported phenomena. Changes in the highly adaptive skeletal muscle may precede changes seen in other tissue types so analysis of the transcriptome/metabolome could have great value in prognosis and diagnosis. It is possible to conduct such studies in humans although such experiments are logistically complicated, requiring appropriate subject numbers that adhere to complicated inclusion and exclusion criteria and expensive consumables. It could however be argued that a more beneficial approach would be to utilise a "pre-clinical model" to further refine and develop hypotheses before introduction in the human being. This approach would clearly also decrease the need for animal work.

A number of animal models of arthritis have been developed to study arthritic disease pathogenesis and evaluate the efficacy of candidate anti-inflammatory and anti-arthritic drugs for clinical development [161-167]. These animal models may involve injection of inflammatory agents into the joint, surgical creation of joint instability or surgical replication of joint trauma. Such models not only cause a considerable amount of pain and suffering but also none of them have a proven track record of predictability in human disease. Consequently, there is an acute need for developing novel and alternative in vitro models that mimic the biology of cartilage [168-172]. Many studies have used articular cartilage and synovial tissues to establish in vitro models of the joint. In our laboratories we have developed explant models of articular cartilage inflammation, co-cultures of primary synoviocytes and chondrocytes as well as 3dimensional high-density cultures of chondrocytes and MSCs [152, 153, 173-175]. We have also determined the potential of phytochemicals as stimulators of chondrogenic differentiation. These culture models of MSCs, fully differentiated cells and co-cultures have potential as "proof of principle" ethically acceptable "3Rs" models for engineering biomimetic models of articular cartilage in vitro for the purpose of replacing and reducing the use of animals in arthritis research. This approach could help reduce the number of laboratory animals used in arthritis research and may provide a realistic alternative to experimental animals. 
Articular cartilage damage is a persistent and increasing problem as the ageing population expands and treatments to achieve biological repair have been challenging [176]. Cartilage tissue engineering has been around for over 20 years. However, none of the approaches available so far have been able to achieve the consistency, effectiveness and reliability that are required for clinical applications. Tissue engineering of a mechanically resilient cartilage construct that meets the structural and functional criteria for effective functional integration into a defect site in the host is a difficult endeavour [177]. One of the fundamental weaknesses of all the models available to date is that none of them possess the normal zonal organization of chondrocytes that is seen in vivo (i.e. superficial, middle, deep and calcified zones) and the local composition of extracellular matrix in each zone. This structural organisation is a prerequisite for normal cartilage function and the success of any future clinical applications. The currently available 3-D models produce fairly homogeneous populations of cells without the ability to achieve any zonal organization in vitro [176]. The ability to produce a construct that recapitulates the zonal and structural architecture of the original tissue is currently lacking. Even the mechanically stable scaffolds that have been created so far do not allow regeneration of a sufficiently large mass of structurally and functionally competent cartilage construct especially if they were constructed and seeded with 2-D passaged (monolayer) chondrocytes in combination with a biomimetic carrier or scaffold [177]. This is one reason why future studies must begin with 3-D cultured chondrocytes maintained in a physiologically relevant microenvironment that replicates the ionic, osmotic and biomechanical milieu of cartilage. The 3-D and microenvironmental impact on cell phenotype is a significant factor creating cartilage constructs within biomimetic scaffold constructs [177].

In summary, it may be difficult to imagine research being done without animal models but it is worth pointing out that in vitro models of joint and musculoskeletal tissues have been around for several decades and new researchers are increasingly adopting them for work on musculoskeletal diseases. Therefore, it is our optimistic view that in future many animal models could potentially be replaced with biomimetic and animal sparing alternatives in a variety of research disciplines and applications.

\section{Acknowledgements}

A. Mobasheri acknowledges the financial support of The Wellcome Trust, the National Centre for the Replacement, Refinement and Reduction of Animals in Research (NC3Rs) (grant number: Mobasheri.A.28102007), the Biotechnology and Biological Sciences Research Council (BBSRC) (grants BBSRC/S/M/2006/ 13141 and BB/G018030/1), the Engineering and Physical Sciences Research Council (EPSRC), Arthritis Research UK (ARUK) and the European Commission Framework 7 (EU FP7). M. Lewis acknowledges the financial support of the National Centre for the Replacement, Refinement and Reduction of Animals in Research (NC3Rs), the Engineering and Physical Sciences Research Council (EPSRC), Arthritis Research UK (ARUK), The Wellcome Trust, the National Centre for Sport and Exercise Medicine (NCSEM). 


\section{Author details}

Ali Mobasheri ${ }^{1}$ and Mark Lewis ${ }^{2}$

1 Arthritis Research UK Centre for Sport, Exercise and Osteoarthritis, Arthritis Research UK Pain Centre, Medical Research Council and Arthritis Research UK Centre for Musculoskeletal Ageing Research, The University of Nottingham, Musculoskeletal Research Group, Division of Veterinary Medicine, School of Veterinary Medicine and Science, Faculty of Medicine and Health Science, The University of Nottingham, Sutton Bonington Campus, Sutton Bonington, Leicestershire, UK

2 Arthritis Research UK Centre for Sport, Exercise and Osteoarthritis, Musculoskeletal Biology Research Group, School of Sport, Exercise and Health Sciences, Loughborough University, Loughborough, Leicestershire, UK

\section{References}

[1] Langer R, Vacanti JP. Tissue engineering. Science. 1993;260(5110):920-6. Epub 1993/05/14.

[2] Fuchs JR, Nasseri BA, Vacanti JP. Tissue engineering: a 21st century solution to surgical reconstruction. Ann Thorac Surg. 2001;72(2):577-91. Epub 2001/08/23.

[3] Kaihara S, Vacanti JP. Tissue engineering: toward new solutions for transplantation and reconstructive surgery. Arch Surg. 1999;134(11):1184-8. Epub 1999/11/11.

[4] Vincent JF, Bogatyreva OA, Bogatyrev NR, Bowyer A, Pahl AK. Biomimetics: its practice and theory. J R Soc Interface. 2006;3(9):471-82. Epub 2006/07/20.

[5] Harrison R. The outgrowth of the nerve fiber as a mode of protoplasmic movement. J Exp Zool. 1910;9:787-846.

[6] Witkowski JA. Experimental pathology and the origins of tissue culture: Leo Loeb's contribution. Med Hist. 1983;27(3):269-88. Epub 1983/07/01.

[7] Earle WR. Production of malignancy in vitro. IV. The mouse fibroblast cultures and changes seen in the living cells. J Nat Cancer Inst. 1943;4:165-212.

[8] Scherer WF, Syverton JT, Gey GO. Studies on the propagation in vitro of poliomyelitis viruses. IV. Viral multiplication in a stable strain of human malignant epithelial cells (strain HeLa) derived from an epidermoid carcinoma of the cervix. J Exp Med. 1953;97(5):695-710. Epub 1953/05/01.

[9] Kilkenny C, Parsons N, Kadyszewski E, Festing MF, Cuthill IC, Fry D, et al. Survey of the quality of experimental design, statistical analysis and reporting of research using animals. PLoS One. 2009;4(11):e7824. Epub 2009/12/04. 
[10] Hawke TJ, Garry DJ. Myogenic satellite cells: physiology to molecular biology. J Appl Physiol. 2001;91(2):534-51. Epub 2001/07/18.

[11] Buckingham M, Bajard L, Chang T, Daubas P, Hadchouel J, Meilhac S, et al. The formation of skeletal muscle: from somite to limb. J Anat. 2003;202(1):59-68. Epub 2003/02/18.

[12] Sabourin LA, Rudnicki MA. The molecular regulation of myogenesis. Clin Genet. 2000;57(1):16-25. Epub 2000/03/25.

[13] Buckingham M, Bajard L, Daubas P, Esner M, Lagha M, Relaix F, et al. Myogenic progenitor cells in the mouse embryo are marked by the expression of Pax3/7 genes that regulate their survival and myogenic potential. Anat Embryol (Berl). 2006;211 Suppl 1:51-6. Epub 2006/10/14.

[14] Lepper C, Conway SJ, Fan CM. Adult satellite cells and embryonic muscle progenitors have distinct genetic requirements. Nature. 2009;460(7255):627-31. Epub 2009/06/26.

[15] Kassar-Duchossoy L, Gayraud-Morel B, Gomes D, Rocancourt D, Buckingham M, Shinin V, et al. Mrf4 determines skeletal muscle identity in Myf5:Myod double-mutant mice. Nature. 2004;431(7007):466-71. Epub 2004/09/24.

[16] Rudnicki MA, Schnegelsberg PN, Stead RH, Braun T, Arnold HH, Jaenisch R. MyoD or Myf-5 is required for the formation of skeletal muscle. Cell. 1993;75(7):1351-9. Epub 1993/12/31.

[17] Relaix F, Rocancourt D, Mansouri A, Buckingham M. A Pax3/Pax7-dependent population of skeletal muscle progenitor cells. Nature. 2005;435(7044):948-53. Epub 2005/04/22.

[18] Gros J, Manceau M, Thome V, Marcelle C. A common somitic origin for embryonic muscle progenitors and satellite cells. Nature. 2005;435(7044):954-8. Epub 2005/04/22.

[19] Mauro A. Satellite cell of skeletal muscle fibers. J Biophys Biochem Cytol. 1961;9:493-5. Epub 1961/02/01.

[20] Seale P, Sabourin LA, Girgis-Gabardo A, Mansouri A, Gruss P, Rudnicki MA. Pax7 is required for the specification of myogenic satellite cells. Cell. 2000;102(6):777-86. Epub 2000/10/13.

[21] Gnocchi VF, White RB, Ono Y, Ellis JA, Zammit PS. Further characterisation of the molecular signature of quiescent and activated mouse muscle satellite cells. PLoS One. 2009;4(4):e5205. Epub 2009/04/17.

[22] Beauchamp JR, Heslop L, Yu DS, Tajbakhsh S, Kelly RG, Wernig A, et al. Expression of CD34 and Myf5 defines the majority of quiescent adult skeletal muscle satellite cells. J Cell Biol. 2000;151(6):1221-34. Epub 2000/12/21. 
[23] Bischoff R. A satellite cell mitogen from crushed adult muscle. Dev Biol. 1986;115(1): 140-7. Epub 1986/05/01.

[24] Yang H, Alnaqeeb M, Simpson H, Goldspink G. Changes in muscle fibre type, muscle mass and IGF-I gene expression in rabbit skeletal muscle subjected to stretch. J Anat. 1997;190 ( Pt 4):613-22. Epub 1997/05/01.

[25] Haddad F, Adams GR. Selected contribution: acute cellular and molecular responses to resistance exercise. J Appl Physiol. 2002;93(1):394-403. Epub 2002/06/19.

[26] Hameed M, Orrell RW, Cobbold M, Goldspink G, Harridge SD. Expression of IGF-I splice variants in young and old human skeletal muscle after high resistance exercise. J Physiol. 2003;547(Pt 1):247-54. Epub 2003/02/04.

[27] Hill M, Goldspink G. Expression and splicing of the insulin-like growth factor gene in rodent muscle is associated with muscle satellite (stem) cell activation following local tissue damage. J Physiol. 2003;549(Pt 2):409-18. Epub 2003/04/15.

[28] Tatsumi R, Sheehan SM, Iwasaki H, Hattori A, Allen RE. Mechanical stretch induces activation of skeletal muscle satellite cells in vitro. Exp Cell Res. 2001;267(1):107-14. Epub 2001/06/20.

[29] Tatsumi R, Hattori A, Ikeuchi Y, Anderson JE, Allen RE. Release of hepatocyte growth factor from mechanically stretched skeletal muscle satellite cells and role of pH and nitric oxide. Mol Biol Cell. 2002;13(8):2909-18. Epub 2002/08/16.

[30] Roeder RA, Hossner KL, Sasser RG, Gunn JM. Regulation of protein turnover by recombinant human insulin-like growth factor-I in L6 myotube cultures. Horm Metab Res. 1988;20(11):698-700. Epub 1988/11/01.

[31] Engert JC, Berglund EB, Rosenthal N. Proliferation precedes differentiation in IGF-Istimulated myogenesis. J Cell Biol. 1996;135(2):431-40. Epub 1996/10/01.

[32] Yang SY, Goldspink G. Different roles of the IGF-I Ec peptide (MGF) and mature IGF-I in myoblast proliferation and differentiation. FEBS Lett. 2002;522(1-3):156-60. Epub 2002/07/04.

[33] Ates K, Yang SY, Orrell RW, Sinanan AC, Simons P, Solomon A, et al. The IGF-I splice variant MGF increases progenitor cells in ALS, dystrophic, and normal muscle. FEBS Lett. 2007;581(14):2727-32. Epub 2007/05/29.

[34] Kandalla PK, Goldspink G, Butler-Browne G, Mouly V. Mechano Growth Factor E peptide (MGF-E), derived from an isoform of IGF-1, activates human muscle progenitor cells and induces an increase in their fusion potential at different ages. Mech Ageing Dev. 2011;132(4):154-62. Epub 2011/03/01.

[35] Tatsumi R, Anderson JE, Nevoret CJ, Halevy O, Allen RE. HGF/SF is present in normal adult skeletal muscle and is capable of activating satellite cells. Dev Biol. 1998;194(1):114-28. Epub 1998/03/14. 
[36] Zammit PS, Heslop L, Hudon V, Rosenblatt JD, Tajbakhsh S, Buckingham ME, et al. Kinetics of myoblast proliferation show that resident satellite cells are competent to fully regenerate skeletal muscle fibers. Exp Cell Res. 2002;281(1):39-49. Epub $2002 / 11 / 21$.

[37] Cornelison DD, Wold BJ. Single-cell analysis of regulatory gene expression in quiescent and activated mouse skeletal muscle satellite cells. Dev Biol. 1997;191(2):270-83. Epub 1997/12/17.

[38] Kuang S, Kuroda K, Le Grand F, Rudnicki MA. Asymmetric self-renewal and commitment of satellite stem cells in muscle. Cell. 2007;129(5):999-1010. Epub 2007/06/02.

[39] Troy A, Cadwallader AB, Fedorov Y, Tyner K, Tanaka KK, Olwin BB. Coordination of Satellite Cell Activation and Self-Renewal by Par-Complex-Dependent Asymmetric Activation of p38alpha/beta MAPK. Cell Stem Cell. 2012;11(4):541-53. Epub 2012/10/09.

[40] Conboy IM, Rando TA. The regulation of Notch signaling controls satellite cell activation and cell fate determination in postnatal myogenesis. Dev Cell. 2002;3(3): 397-409. Epub 2002/10/04.

[41] Zammit PS, Golding JP, Nagata Y, Hudon V, Partridge TA, Beauchamp JR. Muscle satellite cells adopt divergent fates: a mechanism for self-renewal? J Cell Biol. 2004;166(3):347-57. Epub 2004/07/28.

[42] Edom F, Mouly V, Barbet JP, Fiszman MY, Butler-Browne GS. Clones of human satellite cells can express in vitro both fast and slow myosin heavy chains. Dev Biol. 1994;164(1):219-29. Epub 1994/07/01.

[43] Brady MA, Lewis MP, Mudera V. Synergy between myogenic and non-myogenic cells in a 3D tissue-engineered craniofacial skeletal muscle construct. J Tissue Eng Regen Med. 2008;2(7):408-17. Epub 2008/08/23.

[44] Agley CC, Velloso CP, Lazarus NR, Harridge SD. An image analysis method for the precise selection and quantitation of fluorescently labeled cellular constituents: application to the measurement of human muscle cells in culture. J Histochem Cytochem. 2012;60(6):428-38. Epub 2012/04/19.

[45] Smith AS, Passey S, Greensmith L, Mudera V, Lewis MP. Characterization and optimization of a simple, repeatable system for the long term in vitro culture of aligned myotubes in 3D. J Cell Biochem. 2012;113(3):1044-53. Epub 2011/11/09.

[46] Doumit ME, Merkel RA. Conditions for isolation and culture of porcine myogenic satellite cells. Tissue Cell. 1992;24(2):253-62. Epub 1992/01/01.

[47] Di Carlo A, De Mori R, Martelli F, Pompilio G, Capogrossi MC, Germani A. Hypoxia inhibits myogenic differentiation through accelerated MyoD degradation. J Biol Chem. 2004;279(16):16332-8. Epub 2004/02/03. 
[48] Liu W, Wen Y, Bi P, Lai X, Liu XS, Liu X, et al. Hypoxia promotes satellite cell selfrenewal and enhances the efficiency of myoblast transplantation. Development. 2012;139(16):2857-65. Epub 2012/07/06.

[49] Bigot A, Jacquemin V, Debacq-Chainiaux F, Butler-Browne GS, Toussaint O, Furling $\mathrm{D}$, et al. Replicative aging down-regulates the myogenic regulatory factors in human myoblasts. Biol Cell. 2008;100(3):189-99. Epub 2007/11/09.

[50] Sinanan AC, Hunt NP, Lewis MP. Human adult craniofacial muscle-derived cells: neural-cell adhesion-molecule (NCAM; CD56)-expressing cells appear to contain multipotential stem cells. Biotechnol Appl Biochem. 2004;40(Pt 1):25-34. Epub 2004/07/24.

[51] Stern MM, Myers RL, Hammam N, Stern KA, Eberli D, Kritchevsky SB, et al. The influence of extracellular matrix derived from skeletal muscle tissue on the proliferation and differentiation of myogenic progenitor cells ex vivo. Biomaterials. 2009;30(12):2393-9. Epub 2009/01/27.

[52] Sinanan AC, Machell JR, Wynne-Hughes GT, Hunt NP, Lewis MP. Alpha v beta 3 and alpha $\mathrm{v}$ beta 5 integrins and their role in muscle precursor cell adhesion. Biol Cell. 2008;100(8):465-77. Epub 2008/02/20.

[53] Hinds S, Bian W, Dennis RG, Bursac N. The role of extracellular matrix composition in structure and function of bioengineered skeletal muscle. Biomaterials. 2011;32(14): 3575-83. Epub 2011/02/18.

[54] Gillies AR, Lieber RL. Structure and function of the skeletal muscle extracellular matrix. Muscle Nerve. 2011;44(3):318-31. Epub 2011/09/29.

[55] Acarturk TO, Peel MM, Petrosko P, LaFramboise W, Johnson PC, DiMilla PA. Control of attachment, morphology, and proliferation of skeletal myoblasts on silanized glass. J Biomed Mater Res. 1999;44(4):355-70. Epub 1999/07/09.

[56] Saxena AK, Marler J, Benvenuto M, Willital GH, Vacanti JP. Skeletal muscle tissue engineering using isolated myoblasts on synthetic biodegradable polymers: preliminary studies. Tissue Eng. 1999;5(6):525-32. Epub 1999/12/28.

[57] Shah R, Sinanan AC, Knowles JC, Hunt NP, Lewis MP. Craniofacial muscle engineering using a 3-dimensional phosphate glass fibre construct. Biomaterials. 2005;26(13): 1497-505. Epub 2004/11/04.

[58] Ker ED, Nain AS, Weiss LE, Wang J, Suhan J, Amon CH, et al. Bioprinting of growth factors onto aligned sub-micron fibrous scaffolds for simultaneous control of cell differentiation and alignment. Biomaterials. 2011;32(32):8097-107. Epub 2011/08/09.

[59] Vandenburgh HH, Karlisch P, Farr L. Maintenance of highly contractile tissue-cultured avian skeletal myotubes in collagen gel. In Vitro Cell Dev Biol. 1988;24(3): 166-74. Epub 1988/03/01. 
[60] Dennis RG, Kosnik PE, 2nd. Excitability and isometric contractile properties of mammalian skeletal muscle constructs engineered in vitro. In Vitro Cell Dev Biol Anim. 2000;36(5):327-35. Epub 2000/08/11.

[61] Cheema U, Yang SY, Mudera V, Goldspink GG, Brown RA. 3-D in vitro model of early skeletal muscle development. Cell Motil Cytoskeleton. 2003;54(3):226-36. Epub 2003/02/18

[62] Huang YC, Dennis RG, Larkin L, Baar K. Rapid formation of functional muscle in vitro using fibrin gels. J Appl Physiol. 2005;98(2):706-13. Epub 2004/10/12.

[63] Dugan JM, Collins RF, Gough JE, Eichhorn SJ. Oriented surfaces of adsorbed cellulose nanowhiskers promote skeletal muscle myogenesis. Acta Biomater. 2012. Epub 2012/09/12.

[64] Bian W, Bursac N. Engineered skeletal muscle tissue networks with controllable architecture. Biomaterials. 2009;30(7):1401-12. Epub 2008/12/17.

[65] Khodabukus A, Baar K. Defined electrical stimulation emphasizing excitability for the development and testing of engineered skeletal muscle. Tissue Eng Part C Methods. 2012;18(5):349-57. Epub 2011/11/19.

[66] Boonen KJ, Langelaan ML, Polak RB, van der Schaft DW, Baaijens FP, Post MJ. Effects of a combined mechanical stimulation protocol: Value for skeletal muscle tissue engineering. J Biomech. 2010;43(8):1514-21. Epub 2010/03/02.

[67] Mudera V, Smith AS, Brady MA, Lewis MP. The effect of cell density on the maturation and contractile ability of muscle derived cells in a 3D tissue-engineered skeletal muscle model and determination of the cellular and mechanical stimuli required for the synthesis of a postural phenotype. J Cell Physiol. 2010;225(3):646-53. Epub 2010/06/10

[68] Powell CA, Smiley BL, Mills J, Vandenburgh HH. Mechanical stimulation improves tissue-engineered human skeletal muscle. Am J Physiol Cell Physiol. 2002;283(5):C1557-65. Epub 2002/10/10.

[69] Emdad L, Sarkar D, Su ZZ, Boukerche H, Bar-Eli M, Fisher PB. Progression elevated gene-3 (PEG-3) induces pleiotropic effects on tumor progression: modulation of genomic stability and invasion. J Cell Physiol. 2005;202(1):135-46. Epub 2004/09/25.

[70] Rao N, Evans S, Stewart D, Spencer KH, Sheikh F, Hui EE, et al. Fibroblasts influence muscle progenitor differentiation and alignment in contact independent and dependent manners in organized co-culture devices. Biomed Microdevices. 2012. Epub 2012/09/18

[71] Cheema U, Brown R, Mudera V, Yang SY, McGrouther G, Goldspink G. Mechanical signals and IGF-I gene splicing in vitro in relation to development of skeletal muscle. J Cell Physiol. 2005;202(1):67-75. Epub 2004/09/25. 
[72] Moskowitz RW. Experimental models of degenerative joint disease. Semin Arthritis Rheum. 1972;2(1):95-116. Epub 1972/01/01.

[73] van den Berg WB. Animal models of arthritis. What have we learned? J Rheumatol Suppl. 2005;72:7-9. Epub 2005/01/22.

[74] Bendele A, McComb J, Gould T, McAbee T, Sennello G, Chlipala E, et al. Animal models of arthritis: relevance to human disease. Toxicol Pathol. 1999;27(1):134-42. Epub 1999/06/15.

[75] Billingham ME. Models of arthritis and the search for anti-arthritic drugs. Pharmacol Ther. 1983;21(3):389-428. Epub 1983/01/01.

[76] Rainsford KD. Adjuvant polyarthritis in rats: is this a satisfactory model for screening anti-arthritic drugs? Agents Actions. 1982;12(4):452-8. Epub 1982/10/01.

[77] Magilavy DB. Animal models of chronic inflammatory arthritis. Clin Orthop Relat Res. 1990(259):38-45. Epub 1990/10/01.

[78] Sokoloff L. Animal models of rheumatoid arthritis. Int Rev Exp Pathol. 1984;26:107-45. Epub 1984/01/01.

[79] Hadler NM. A pathogenetic model for erosive synovitis: lessons from animal arthritides. Arthritis Rheum. 1976;19(2):256-66. Epub 1976/03/01.

[80] Trentham DE. Collagen arthritis as a relevant model for rheumatoid arthritis. Arthritis Rheum. 1982;25(8):911-6. Epub 1982/08/01.

[81] Trentham DE. Immunity to type II collagen in rheumatoid arthritis: a current appraisal. Proc Soc Exp Biol Med. 1984;176(2):95-104. Epub 1984/06/01.

[82] Stuart JM, Townes AS, Kang AH. Collagen autoimmune arthritis. Annu Rev Immunol. 1984;2:199-218. Epub 1984/01/01.

[83] Schwartz ER, Greenwald RA. Experimental models of osteoarthritis. Bull Rheum Dis. 1979;30(6):1030-3. Epub 1979/01/01.

[84] Miller DR, Lust G. Accumulation of procollagen in the degenerative articular cartilage of dogs with osteoarthritis. Biochim Biophys Acta. 1979;583(2):218-31.

[85] Bendele AM, Hulman JF. Spontaneous cartilage degeneration in guinea pigs. Arthritis Rheum. 1988;31(4):561-5.

[86] Pond MJ, Nuki G. Experimentally-induced osteoarthritis in the dog. Ann Rheum Dis. 1973;32(4):387-8.

[87] Janusz MJ, Bendele AM, Brown KK, Taiwo YO, Hsieh L, Heitmeyer SA. Induction of osteoarthritis in the rat by surgical tear of the meniscus: Inhibition of joint damage by a matrix metalloproteinase inhibitor. Osteoarthritis Cartilage. 2002;10(10):785-91. 
[88] Simmons EJ, Bertone AL, Weisbrode SE. Instability-induced osteoarthritis in the metacarpophalangeal joint of horses. Am J Vet Res. 1999;60(1):7-13.

[89] Marijnissen AC, van Roermund PM, TeKoppele JM, Bijlsma JW, Lafeber FP. The canine 'groove' model, compared with the ACLT model of osteoarthritis. Osteoarthritis Cartilage. 2002;10(2):145-55.

[90] Kawcak CE, Frisbie DD, Werpy NM, Park RD, Mcllwraith CW. Effects of exercise vs experimental osteoarthritis on imaging outcomes. Osteoarthritis Cartilage. 2008;16(12):1519-25.

[91] Bentley G. Papain-induced degenerative arthritis of the hip in rabbits. J Bone Joint Surg Br. 1971;53(2):324-37.

[92] Gustafson SB, Trotter GW, Norrdin RW, Wrigley RH, Lamar C. Evaluation of intraarticularly administered sodium monoiodoacetate-induced chemical injury to articular cartilage of horses. Am J Vet Res. 1992;53(7):1193-202.

[93] van der Kraan PM, Vitters EL, van Beuningen HM, van de Putte LB, van den Berg WB. Degenerative knee joint lesions in mice after a single intra-articular collagenase injection. A new model of osteoarthritis. J Exp Pathol (Oxford). 1990;71(1):19-31.

[94] Fässler R, Schnegelsberg PN, Dausman J, Shinya T, Muragaki Y, McCarthy MT, et al. Mice lacking alpha 1 (IX) collagen develop noninflammatory degenerative joint disease. Proc Natl Acad Sci U S A. 1994;91(11):5070-4.

[95] Ameye L, Aria D, Jepsen K, Oldberg A, Xu T, Young MF. Abnormal collagen fibrils in tendons of biglycan/fibromodulin-deficient mice lead to gait impairment, ectopic ossification, and osteoarthritis. Faseb J. 2002;16(7):673-80.

[96] Bora FW, Jr., Miller G. Joint physiology, cartilage metabolism, and the etiology of osteoarthritis. Hand Clin. 1987;3(3):325-36. Epub 1987/08/01.

[97] Benedek TG. A history of the understanding of cartilage. Osteoarthritis Cartilage. 2006;14(3):203-9. Epub 2005/10/26.

[98] Holtzer H. Control of Chondrogenesis in the Embryo. Biophys J. 1964;4:SUPPL239-55. Epub 1964/01/01.

[99] Lash JW, Holtzer H, Whitehouse MW. In vitro studies on chondrogenesis; the uptake of radioactive sulfate during cartilage induction. Dev Biol. 1960;2:76-89. Epub 1960/02/01.

[100] Kawiak J, Moskalewski S, Darzynkiewicz Z. Isolation of chondrocytes from calf cartilage. Exp Cell Res. 1965;39(1):59-68. Epub 1965/08/01.

[101] Manning WK, Bonner WM, Jr. Isolation and culture of chondrocytes from human adult articular cartilage. Arthritis Rheum. 1967;10(3):235-9. Epub 1967/06/01. 
[102] Malemud CJ, Sokoloff L. Some biological characteristics of a pituitary growth factor (CGF) for cultured lapine articular chondrocytes. J Cell Physiol. 1974;84(2):171-9. Epub 1974/10/01.

[103] Corvol MT, Malemud CJ, Sokoloff L. A pituitary growth-promoting factor for articular chondrocytes in monolayer culture. Endocrinology. 1972;90(1):262-71. Epub 1972/01/01.

[104] Craig CP, Gordon SL, Greer RB. Interferon responsiveness of rabbit synovial cells and chondrocytes. Infect Immun. 1973;8(3):425-9. Epub 1973/09/01.

[105] Sachs BL, Goldberg VM, Moskowitz RW, Malemud CJ. Response of articular chondrocytes to pituitary fibroblast growth factor (FGF). J Cell Physiol. 1982;112(1):51-9. Epub 1982/07/01.

[106] Thenet S, Benya PD, Demignot S, Feunteun J, Adolphe M. SV40-immortalization of rabbit articular chondrocytes: alteration of differentiated functions. J Cell Physiol. 1992;150(1):158-67. Epub 1992/01/01.

[107] Pufe T, Harde V, Petersen W, Goldring MB, Tillmann B, Mentlein R. Vascular endothelial growth factor (VEGF) induces matrix metalloproteinase expression in immortalized chondrocytes. J Pathol. 2004;202(3):367-74. Epub 2004/03/03.

[108] Tomford WW, Fredericks GR, Mankin HJ. Studies on cryopreservation of articular cartilage chondrocytes. J Bone Joint Surg Am. 1984;66(2):253-9. Epub 1984/02/01.

[109] Schachar N, Nagao M, Matsuyama T, McAllister D, Ishii S. Cryopreserved articular chondrocytes grow in culture, maintain cartilage phenotype, and synthesize matrix components. J Orthop Res. 1989;7(3):344-51. Epub 1989/01/01.

[110] Nixon AJ, Lust G, Vernier-Singer M. Isolation, propagation, and cryopreservation of equine articular chondrocytes. Am J Vet Res. 1992;53(12):2364-70. Epub 1992/12/01.

[111] Almqvist KF, Wang L, Broddelez C, Veys EM, Verbruggen G. Biological freezing of human articular chondrocytes. Osteoarthritis Cartilage. 2001;9(4):341-50. Epub 2001/06/12.

[112] Abbott J, Holtzer H. The loss of phenotypic traits by differentiated cells. 3 . The reversible behavior of chondrocytes in primary cultures. J Cell Biol. 1966;28(3):473-87. Epub 1966/03/01.

[113] Wright E, Hargrave MR, Christiansen J, Cooper L, Kun J, Evans T, et al. The Sry-related gene Sox9 is expressed during chondrogenesis in mouse embryos. Nat Genet. 1995;9(1):15-20. Epub 1995/01/01.

[114] Huang W, Chung UI, Kronenberg HM, de Crombrugghe B. The chondrogenic transcription factor Sox9 is a target of signaling by the parathyroid hormone-related peptide in the growth plate of endochondral bones. Proc Natl Acad Sci U S A. 2001;98(1): 160-5. Epub 2000/12/20. 
[115] Ng LJ, Wheatley S, Muscat GE, Conway-Campbell J, Bowles J, Wright E, et al. SOX9 binds DNA, activates transcription, and coexpresses with type II collagen during chondrogenesis in the mouse. Dev Biol. 1997;183(1):108-21. Epub 1997/03/01.

[116] Guo JF, Jourdian GW, MacCallum DK. Culture and growth characteristics of chondrocytes encapsulated in alginate beads. Connect Tissue Res. 1989;19(2-4):277-97. Epub 1989/01/01.

[117] Hauselmann HJ, Aydelotte MB, Schumacher BL, Kuettner KE, Gitelis SH, Thonar EJ. Synthesis and turnover of proteoglycans by human and bovine adult articular chondrocytes cultured in alginate beads. Matrix. 1992;12(2):116-29. Epub 1992/04/01.

[118] Maldonado BA, Oegema TR, Jr. Initial characterization of the metabolism of intervertebral disc cells encapsulated in microspheres. J Orthop Res. 1992;10(5):677-90. Epub 1992/09/11.

[119] Thonar E, An H, Masuda K. Compartmentalization of the matrix formed by nucleus pulposus and annulus fibrosus cells in alginate gel. Biochem Soc Trans. 2002;30(Pt 6): 874-8. Epub 2002/11/21.

[120] Ramdi H, Tahri Jouti MA, Lievremont M. Immobilized articular chondrocytes: in vitro production of extracellular matrix compounds. Biomater Artif Cells Immobilization Biotechnol. 1993;21(3):335-41. Epub 1993/01/01.

[121] Masuda K, Shirota H, Thonar EJ. Quantification of 35S-labeled proteoglycans complexed to alcian blue by rapid filtration in multiwell plates. Anal Biochem. 1994;217(2):167-75. Epub 1994/03/01.

[122] Hauselmann HJ, Oppliger L, Michel BA, Stefanovic-Racic M, Evans CH. Nitric oxide and proteoglycan biosynthesis by human articular chondrocytes in alginate culture. FEBS Lett. 1994;352(3):361-4. Epub 1994/10/03.

[123] Bonaventure J, Kadhom N, Cohen-Solal L, Ng KH, Bourguignon J, Lasselin C, et al. Reexpression of cartilage-specific genes by dedifferentiated human articular chondrocytes cultured in alginate beads. Exp Cell Res. 1994;212(1):97-104. Epub 1994/05/01.

[124] Hauselmann HJ, Fernandes RJ, Mok SS, Schmid TM, Block JA, Aydelotte MB, et al. Phenotypic stability of bovine articular chondrocytes after long-term culture in alginate beads. J Cell Sci. 1994;107 ( Pt 1):17-27. Epub 1994/01/01.

[125] Paige KT, Vacanti CA. Engineering new tissue: formation of neo-cartilage. Tissue Eng. 1995;1(2):97-106. Epub 1995/07/01.

[126] Hascall VC, Oegema TR, Brown M. Isolation and characterization of proteoglycans from chick limb bud chondrocytes grown in vitro. J Biol Chem. 1976;251(11):3511-9. Epub 1976/06/10. 
[127] Wiebkin OW, Muir H. Synthesis of cartilage-specific proteoglycan by suspension cultures of adult chondrocytes. Biochem J. 1977;164(1):269-72. Epub 1977/04/15.

[128] Bjornsson S, Heinegard D. Fractionation and characterization of proteoglycans isolated from chondrocyte cell cultures. Biochem J. 1981;197(2):249-58. Epub 1981/08/01.

[129] Yasui N, Osawa S, Ochi T, Nakashima H, Ono K. Primary culture of chondrocytes embedded in collagen gels. Exp Cell Biol. 1982;50(2):92-100. Epub 1982/01/01.

[130] Benya PD, Shaffer JD. Dedifferentiated chondrocytes reexpress the differentiated collagen phenotype when cultured in agarose gels. Cell. 1982;30(1):215-24. Epub 1982/08/01.

[131] Lemare F, Steimberg N, Le Griel C, Demignot S, Adolphe M. Dedifferentiated chondrocytes cultured in alginate beads: restoration of the differentiated phenotype and of the metabolic responses to interleukin-1beta. J Cell Physiol. 1998;176(2):303-13. Epub 1998/07/02.

[132] Buschmann MD, Gluzband YA, Grodzinsky AJ, Kimura JH, Hunziker EB. Chondrocytes in agarose culture synthesize a mechanically functional extracellular matrix. J Orthop Res. 1992;10(6):745-58. Epub 1992/11/01.

[133] Buschmann MD, Gluzband YA, Grodzinsky AJ, Hunziker EB. Mechanical compression modulates matrix biosynthesis in chondrocyte/agarose culture. J Cell Sci. 1995;108 ( Pt 4):1497-508. Epub 1995/04/01.

[134] Elder SH, Goldstein SA, Kimura JH, Soslowsky LJ, Spengler DM. Chondrocyte differentiation is modulated by frequency and duration of cyclic compressive loading. Ann Biomed Eng. 2001;29(6):476-82. Epub 2001/07/19.

[135] Mauck RL, Byers BA, Yuan X, Tuan RS. Regulation of cartilaginous ECM gene transcription by chondrocytes and MSCs in 3D culture in response to dynamic loading. Biomech Model Mechanobiol. 2007;6(1-2):113-25. Epub 2006/05/13.

[136] Lee DA, Noguchi T, Frean SP, Lees P, Bader DL. The influence of mechanical loading on isolated chondrocytes seeded in agarose constructs. Biorheology. 2000;37(1-2): 149-61. Epub 2000/07/27.

[137] Barratt ME. Role of the chondrocytes in the breakdown of pig articular cartilage induced by complement-sufficient antiserum to pig erythrocytes. Int Arch Allergy Appl Immunol. 1975;48(4):547-63. Epub 1975/01/01.

[138] Fell DH. Influence of the pericellular environment on the cells. The role of mucopolysaccharides in the protection of cartilage cells against immune reactions. Philos Trans R Soc Lond B Biol Sci. 1975;271(912):325-41. Epub 1975/07/17.

[139] Kirkpatrick CJ. Cartilage growth inhibition and necrosis in vitro caused by prostaglandin A1. Virchows Arch B Cell Pathol Incl Mol Pathol. 1980;33(1):91-105. Epub 1980/01/01. 
[140] Kirkpatrick CJ. The effects of prostaglandin A1 and prostaglandin B1 on the differentiation of cartilage in the chick embryo. Cell Tissue Res. 1980;210(1):111-20. Epub 1980/01/01.

[141] Copeland M, Lippiello L, Steensland G, Guralnick WC, Mankin HJ. The prostaglandins of articular cartilage. I. Correlates of prostaglandin activity in a chondrocyte culture system. Prostaglandins. 1980;20(6):1075-87. Epub 1980/12/01.

[142] Jacoby RK. Effect of homologous synovial membrane on adult human articular cartilage in organ culture, and failure to influence it with D-penicillamine. Ann Rheum Dis. 1980;39(1):53-8. Epub 1980/02/01.

[143] Malemud CJ, Norby DP, Sokoloff L. Explant culture of human and rabbit articular chondrocytes. Connect Tissue Res. 1978;6(3):171-9. Epub 1978/01/01.

[144] Kuettner KE, Pauli BU, Gall G, Memoli VA, Schenk RK. Synthesis of cartilage matrix by mammalian chondrocytes in vitro. I. Isolation, culture characteristics, and morphology. J Cell Biol. 1982;93(3):743-50. Epub 1982/06/01.

[145] Kuettner KE, Memoli VA, Pauli BU, Wrobel NC, Thonar EJ, Daniel JC. Synthesis of cartilage matrix by mammalian chondrocytes in vitro. II. Maintenance of collagen and proteoglycan phenotype. J Cell Biol. 1982;93(3):751-7. Epub 1982/06/01.

[146] Nevo Z, Dorfman A. Stimulation of chondromucoprotein synthesis in chondrocytes by extracellular chondromucoprotein. Proc Natl Acad Sci U S A. 1972;69(8):2069-72. Epub 1972/08/01.

[147] Handley CJ, Lowther DA. Inhibition of proteoglycan biosynthesis by hyaluronic acid in chondrocytes in cell culture. Biochim Biophys Acta. 1976;444(1):69-74. Epub 1976/08/24.

[148] von der Mark K, von der Mark H. Immunological and biochemical studies of collagen type transition during in vitro chrondrogenesis of chick limb mesodermal cells. J Cell Biol. 1977;73(3):736-47. Epub 1977/06/01.

[149] Lohmander LS, Hascall VC, Caplan AI. Effects of 4-methyl umbelliferyl-beta-D-xylopyranoside on chondrogenesis and proteoglycan synthesis in chick limb bud mesenchymal cell cultures. J Biol Chem. 1979;254(20):10551-61. Epub 1979/10/25.

[150] Hassell JR, Pennypacker JP, Kleinman HK, Pratt RM, Yamada KM. Enhanced cellular fibronectin accumulation in chondrocytes treated with vitamin A. Cell. 1979;17(4): 821-6. Epub 1979/08/01.

[151] Seifarth C, Csaki C, Shakibaei M. Anabolic actions of IGF-I and TGF-beta1 on Interleukin-1beta-treated human articular chondrocytes: evaluation in two and three dimensional cultures. Histol Histopathol. 2009;24(10):1245-62. Epub 2009/08/19. 
[152] Csaki C, Matis U, Mobasheri A, Shakibaei M. Co-culture of canine mesenchymal stem cells with primary bone-derived osteoblasts promotes osteogenic differentiation. Histochem Cell Biol. 2009;131(2):251-66. Epub 2008/10/23.

[153] Csaki C, Matis U, Mobasheri A, Ye H, Shakibaei M. Chondrogenesis, osteogenesis and adipogenesis of canine mesenchymal stem cells: a biochemical, morphological and ultrastructural study. Histochem Cell Biol. 2007;128(6):507-20. Epub 2007/10/09.

[154] Shakibaei M, Seifarth C, John T, Rahmanzadeh M, Mobasheri A. Igf-I extends the chondrogenic potential of human articular chondrocytes in vitro: molecular association between Sox9 and Erk1/2. Biochem Pharmacol. 2006;72(11):1382-95. Epub 2006/10/03.

[155] Shakibaei M, Schroter-Kermani C, Merker HJ. Matrix changes during long-term cultivation of cartilage (organoid or high-density cultures). Histol Histopathol. 1993;8(3): 463-70. Epub 1993/07/01.

[156] Denker AE, Haas AR, Nicoll SB, Tuan RS. Chondrogenic differentiation of murine C3H10T1/2 multipotential mesenchymal cells: I. Stimulation by bone morphogenetic protein-2 in high-density micromass cultures. Differentiation. 1999;64(2):67-76. Epub 1999/05/11.

[157] Loty S, Foll C, Forest N, Sautier JM. Association of enhanced expression of gap junctions with in vitro chondrogenic differentiation of rat nasal septal cartilage-released cells following their dedifferentiation and redifferentiation. Arch Oral Biol. 2000;45(10):843-56. Epub 2000/09/06.

[158] Georgescu HI, Mendelow D, Evans CH. HIG-82: an established cell line from rabbit periarticular soft tissue, which retains the "activatable" phenotype. In Vitro Cell Dev Biol. 1988;24(10):1015-22. Epub 1988/10/01.

[159] Kurz B, Steinhagen J, Schunke M. Articular chondrocytes and synoviocytes in a coculture system: influence on reactive oxygen species-induced cytotoxicity and lipid peroxidation. Cell Tissue Res. 1999;296(3):555-63. Epub 1999/06/17.

[160] Kurz B, Schunke M. Articular chondrocytes and synoviocytes in culture: influence of antioxidants on lipid peroxidation and proliferation. Ann Anat. 1997;179(5):439-46. Epub 1997/10/28.

[161] Goldring MB. The role of cytokines as inflammatory mediators in osteoarthritis: lessons from animal models. Connect Tissue Res. 1999;40(1):1-11. Epub 2000/04/19.

[162] Aigner T, Cook JL, Gerwin N, Glasson SS, Laverty S, Little CB, et al. Histopathology atlas of animal model systems - overview of guiding principles. Osteoarthritis Cartilage. 2010;18 Suppl 3:S2-6. Epub 2010/10/01.

[163] Ameye LG, Young MF. Animal models of osteoarthritis: lessons learned while seeking the "Holy Grail". Curr Opin Rheumatol. 2006;18(5):537-47. Epub 2006/08/10. 
[164] Brandt KD. Transection of the anterior cruciate ligament in the dog: a model of osteoarthritis. Semin Arthritis Rheum. 1991;21(3 Suppl 2):22-32. Epub 1991/12/01.

[165] Brandt KD. Insights into the natural history of osteoarthritis provided by the cruciate-deficient dog. An animal model of osteoarthritis. Ann N Y Acad Sci. 1994;732:199-205. Epub 1994/09/06.

[166] Koch TG, Betts DH. Stem cell therapy for joint problems using the horse as a clinically relevant animal model. Expert Opin Biol Ther. 2007;7(11):1621-6. Epub 2007/10/27.

[167] van den Berg WB. Lessons from animal models of osteoarthritis. Curr Opin Rheumatol. 2001;13(5):452-6. Epub 2001/10/18.

[168] Freed LE, Guilak F, Guo XE, Gray ML, Tranquillo R, Holmes JW, et al. Advanced tools for tissue engineering: scaffolds, bioreactors, and signaling. Tissue Eng. 2006;12(12):3285-305. Epub 2007/05/24.

[169] Sittinger M, Hutmacher DW, Risbud MV. Current strategies for cell delivery in cartilage and bone regeneration. Curr Opin Biotechnol. 2004;15(5):411-8. Epub 2004/10/07.

[170] Reddi AH. Morphogenesis and tissue engineering of bone and cartilage: inductive signals, stem cells, and biomimetic biomaterials. Tissue Eng. 2000;6(4):351-9. Epub 2000/09/19.

[171] Oreffo RO, Triffitt JT. Future potentials for using osteogenic stem cells and biomaterials in orthopedics. Bone. 1999;25(2 Suppl):5S-9S. Epub 1999/08/24.

[172] Reddi AH. Role of morphogenetic proteins in skeletal tissue engineering and regeneration. Nat Biotechnol. 1998;16(3):247-52. Epub 1998/04/07.

[173] Mobasheri A, Csaki C, Clutterbuck AL, Rahmanzadeh M, Shakibaei M. Mesenchymal stem cells in connective tissue engineering and regenerative medicine: applications in cartilage repair and osteoarthritis therapy. Histol Histopathol. 2009;24(3): 347-66. Epub 2009/01/09.

[174] Buhrmann C, Mobasheri A, Matis U, Shakibaei M. Curcumin mediated suppression of nuclear factor-kappaB promotes chondrogenic differentiation of mesenchymal stem cells in a high-density co-culture microenvironment. Arthritis Res Ther. 2010;12(4):R127. Epub 2010/07/03.

[175] Richardson SM, Hoyland JA, Mobasheri R, Csaki C, Shakibaei M, Mobasheri A. Mesenchymal stem cells in regenerative medicine: opportunities and challenges for articular cartilage and intervertebral disc tissue engineering. J Cell Physiol. 2010;222(1): 23-32. Epub 2009/09/03.

[176] Klein TJ, Malda J, Sah RL, Hutmacher DW. Tissue engineering of articular cartilage with biomimetic zones. Tissue Eng Part B Rev. 2009;15(2):143-57. Epub 2009/02/11. 
[177] Hutmacher DW, Ng KW, Kaps C, Sittinger M, Klaring S. Elastic cartilage engineering using novel scaffold architectures in combination with a biomimetic cell carrier. Biomaterials. 2003;24(24):4445-58. Epub 2003/08/19. 
